\title{
The Impact of Electoral Reform on Women's Representation
}

\author{
Pippa Norris \\ John F. Kennedy School of Government, Harvard University, Cambridge, MA 02138, USA. \\ E-mail: Pippa_Norris@Harvard.edu; URL: www.pippanorris.com
}

One concern about reform of the electoral system in the Netherlands is whether this would reduce the proportion of women members in the House of Representatives. What evidence is there for this expectation? This study considers these issues, with the first section summarizing the normative arguments why socially inclusive legislatures are thought to be desirable. The representation of women in the Netherlands parliament is compared against the record in other countries worldwide. The second section analyzes the impact of electoral systems on gender representation, confirming that substantially more women are usually elected in systems using party list proportional representation, especially those such as the Netherlands which have a large district magnitude, compared with majoritarian electoral systems using single member districts. Any reform that moves away from nationwide PR in the Netherlands will therefore probably reduce the proportion of women in parliament unless other compensatory actions are taken. Subsequent sections examine alternative strategies that could be adopted, including statutory quotas regulating the candidate selection process for all parties (for example, as used in Belgium), the role of reserved seats in legislatures, and the use of voluntary quotas in candidate selection rules implemented by particular parties. The conclusion summarizes the main findings and arguments surrounding electoral reform in the Netherlands.

Acta Politica (2006) 41, 197-213. doi:10.1057/palgrave.ap.5500151

Keywords: representation; women; gender; electoral systems

\section{Inclusive Democracy}

Recent decades have witnessed growing demands for the inclusion and empowerment of women and minorities in elected office. Feminist theorists suggest that the presence of women leaders facilitates the articulation of different perspectives on political issues, where elected representatives are not just 'standing as' women but also 'acting for' women as a group (Phillips, 1995, 1998; Mansbridge, 1999). An accumulating body of evidence in North America, Scandinavia and Western Europe suggests that, while not transforming parliaments, women legislators do raise distinctive concerns and issue 
priorities (Duerst-Lahti and Kelly, 1995; Karvonnen and Selle, 1995; Dolan, 1997; Swers, 1998, 2001; Tremblay, 1998; Reingold, 2000; Tremblay and Pelletier, 2000; Carroll, 2001). If so, then the under-representation of women in parliament may have important consequences for the public policy agenda and for the articulation of women's interests, as well as for the legitimacy of democratic bodies. Inclusiveness is widely regarded as one of the key values of democratic polities, so that all major social cleavages have a voice in the policymaking process, whether the politically relevant groups are defined by gender, ethnicity, region, socioeconomic status, age, or education. The inclusion of women is one - but only one dimension - of social diversity.

The broad normative claim underlying these arguments is that legislatures should be more like the societies they serve, reflecting the politically relevant electoral cleavages. In this way, elected bodies meet the criteria of 'descriptive' representation, as Hanna Pitkin (1967) termed this notion. While these claims are widely recognized and acknowledged today, controversy remains about the most effective and appropriate ways to achieve these goals, as well as the priority which should be given to geographic, class, ethnic, and gender representation, where claims may conflict.

By these criteria, most parliaments worldwide fail to reflect the proportion of women in the electorate. This pattern persists, even in established democracies, despite trends in the home, family, school, and work-force transforming women and men's lives during the post-war era, as well as the growth of the more multicultural societies (Inglehart and Norris, 2003). NGOs, parties, and international agencies have often expressed the need for equal opportunities for all citizens in appointed and elected positions in public life. Governments have signed official National Action Plans and international conventions designed to establish conditions of gender equality in the public sphere, exemplified by the 1979 Convention on the Elimination of All Forms of Discrimination against Women (CEDAW) favoring the principle of equal opportunities in public life, ratified by 163 nations. The 1995 UN Beijing Platform for Action expressed commitment to the empowerment of women based on the conviction that: 'Women's empowerment and their full participation on the basis of equality in all spheres of society, including participation in the decision-making process and access to power, are fundamental for the achievement of equality, development and peace.' The UN Platform for Action (1995) explicitly aims for a 50-50 gender balance in all areas of society, and its analysis places full participation in decision-making in the foremost role.

In practice, however, multiple barriers continue to restrict the advancement of women in elected office. According to estimates by the United Nations Development Program (2002), women represent less than one-tenth of the world's cabinet ministers and one-fifth of all sub-ministerial positions. Out of 193 nations worldwide, only nine women are at the pinnacle of power as 
elected heads of State or Government. Despite some redoubtable and wellknown world leaders, only 39 states have ever elected a woman President or Prime Minister. The Inter-Parliamentary Union (2005) estimates that 6,722 women currently sit in both houses of parliament worldwide, representing $15.8 \%$ of all members. This is a rise from $9 \%$ in 1987 yet if growth is maintained at this level $(0.37 \%$ per annum $)$, a simple linear projection predicts that women parliamentarians will achieve parity with men at the turn of the 22nd century.

Regional variations highlight the sharp contrasts in the position of women in elected office. Women parliamentarians do best in the Nordic nations, constituting $40 \%$ of MPs in the lower house. In Sweden, for example, women are half of all Cabinet Ministers and 149 female members sit in the Riksdag $(43 \%)$, quadrupling from $10 \%$ in 1950 . Women political leaders have also moved ahead in the other Nordic countries (Bergqvist et al., 1999). In other global regions the proportion of women members of parliament is usually lower, including in the Americas (19\%), Europe excluding the Nordic states $(17 \%)$, Asia (15\%), Sub-Saharan Africa (16\%), and the Pacific (11\%). Despite some recent reforms in Morocco, Bahrain and Iraq, the worst record remains in Arab states, where women are $9 \%$ of elected representatives. Women continue to be barred by law from standing for parliament in Qatar, Saudi Arabia, Oman, and the United Arab Emirates. The level of human development and the length of democratic experience may be important for achieving gender equality in parliaments, but these are neither necessary nor sufficient factors; in Rwanda, Mexico, Lithuania, and the Czech Republic, for example, women politicians are more successful than in the United States and Japan, two of the most affluent democracies in the world.

In the light of these global patterns, the contemporary record of the Netherlands is impressive, as one of the countries that has led the world in the representation of women in parliament. The Inter-Parliamentary Union (2005) ranks the Netherlands sixth highest worldwide in the proportion of women in parliament, beaten only by the Scandinavian nations with a long tradition of gender equality in political leadership, as well as more recently by Rwanda. Nor is this a temporary phenomenon; the Netherlands has consistently been ranked fifth or sixth in this world league table for at least two decades. The proportion of women in the Tweede Kamer was fairly low from 1922 until 1972, and it then grew steadily in successive elections (with the exception of a slight dip in 2002), rising to 59 women in the lower house in 2005 or $39.3 \%$ (see Figure 1) (for details, see Leijenaar, 2004). This figure is high when compared against the global picture, and it is almost double the EU average $(22.7 \%)$.

Gender is not the only criteria for the inclusiveness of representative bodies, by any means. The class and educational background of elected members have long been a matter of concern in many established democracies, with the 


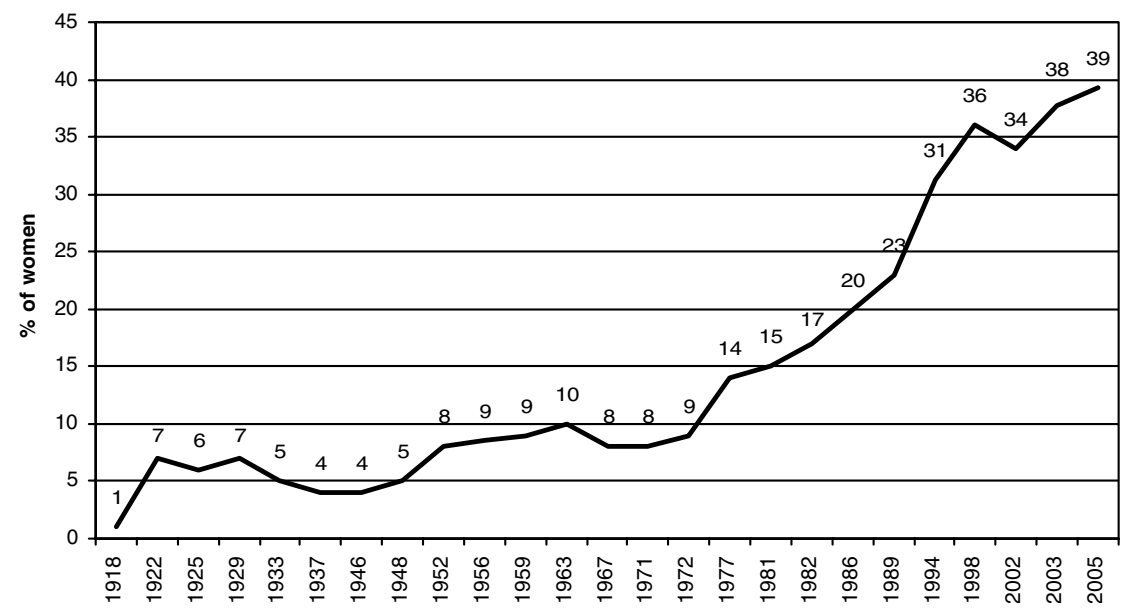

Figure 1 The growth in the proportion of women members in the Tweede Kamer, 1918-2005. Source: Constructed from tables in Chapter 5 of Monique Leijenaar (2004).

under-representation of manual workers, and in recent years the issue of including more ethnic minority representatives has arisen in importance. In this regard, compared with size of the foreign-born population, ethnic minorities are represented almost proportionally in the Tweede Kamer. An analysis of the biographies of current members of the House of Representatives, classified by place of birth, indicates that 13 out of 150 members were born overseas $(8.7 \%)^{1}$. This compares with a foreign-born population in the Netherlands estimated by the OECD (2005) to include 1.7 million people or $10.6 \%$ of the total population.

Given this record, if the Netherlands introduces some single-member districts, the challenge would be how to maintain and preserve gender diversity in elected office. Three main policy options are open for consideration by parliament including the basic type of electoral system that is selected, the introduction of a statutory gender quota regulating the candidate selection process used by all parties, and the use of reserved seats for women in the legislature. Another alternative is that political parties can employ voluntary gender quotas in their candidate selection processes. What are the pros and cons of these options?

\section{The Impact of Electoral Systems}

As discussed earlier in this volume, electoral reform involves multiple alternatives ranging from more modest amendments to the current Dutch 
system of nationwide PR to outright revision. What would be the consequences of reform for the representation of women?

A series of studies since the mid-1980s have confirmed that more women have usually been elected to parliament under party list proportional representation (PR) than under majoritarian electoral systems (Norris, 1985; Matland, 1998; Reynolds, 1999; Kenworthy and Malami, 1999; Siaroff, 2000; Moser, 2001). This pattern holds both within established democracies and also across a broader range of developing societies worldwide. Within proportional electoral systems, the mean district magnitude has commonly been found to be a particularly important factor, with more women usually elected from systems using large multimember constituencies.

The comparison in Table 1, without any controls, illustrates how women are far more successful under PR list systems. The results demonstrate that today around the globe roughly twice as many women get elected to national parliaments under PR (19.6\%) than under majoritarian electoral systems $(10.5 \%)$. 'Combined' or 'mixed' electoral systems fall between these poles $(13.6 \%)$. As a simple rule, therefore, women proved almost twice as likely to be elected under proportional as under majoritarian electoral systems. In 'combined'

Table 1 Women's representation by type of electoral system, 2005

\begin{tabular}{lcr}
\hline & $\begin{array}{c}\text { \% of women in the lower } \\
\text { house of parliament, 2000 }\end{array}$ & Number of nations \\
\hline All majoritarian & 10.5 & 72 \\
Alternative vote & 8.5 & 4 \\
Block vote & 7.4 & 10 \\
Second Ballot & 12.0 & 20 \\
First-past-the-post & 11.4 & 35 \\
Single non-transferable vote & 3.1 & 3 \\
& & 36 \\
All combined & 13.6 & 27 \\
Combined independent & 12.6 & 9 \\
Combined dependent & 16.8 & 67 \\
All proportional & & 2 \\
Single transferable vote & 19.6 & 64 \\
Party list & 11.3 & 175 \\
Total & 19.9 & \\
\hline
\end{tabular}

Note: The percentage of women in the lower house of national parliaments 2005 , 175 nations worldwide. Note that six nations did not hold any elections. For the classification of electoral systems see Norris (2004).

Source: Data on the proportion of women in the lower house of parliament calculated from InterParliamentary Union (2005). 
electoral systems, women candidates enjoy greater success in the more proportional 'combined-dependent' electoral systems $(16.8 \%)$ rather than in the 'combined-independent' systems $(12.6 \%)$.

The comparative evidence has been confirmed in multiple studies but nevertheless the cross-national pattern could be attributed to many other factors associated with PR, however, for example the type of colonial heritage, political culture, the party system, or the level of democratic development of the countries that chose this type of electoral system. Another way to examine the evidence is to consider within country comparisons of simultaneous contests in 'combined' electoral systems where the results for women and men are analyzed by the type of ballot. Here the impact of the electoral system is also confirmed, although the gender differences are usually weaker. As shown in Table 2, in five countries using combined systems, slightly more women were usually elected from the PR party lists than from the single-member districts. It should be emphasized that this contrast is most evident in Italy and Germany; in the former, for example, women are $8.8 \%$ of those elected through the SMDs but they are $18.6 \%$ of the members of the Chamber of Deputies elected via the party lists in multimember districts.

Comparisons can also be drawn with how many women are elected where the electoral system has changed within a particular country, such as New Zealand (NZ). The proportion of women in the NZ parliament grew from $16.5 \%$ in 1990 to $21.2 \%$ in 1993 , immediately after the switch from the SMD plurality to the MMP system, before jumping to $29 \%$ in 1996 , since when the proportion has largely stabilized (Human Rights Commission, 2004). Nevertheless it remains difficult to establish that this development was directly attributable to electoral reform per se, given many other simultaneous changes in the political system, coupled with the observation in

Table 2 The proportion of women MPs in mixed electoral systems in five nations

\begin{tabular}{lccccc}
\hline & \multicolumn{2}{c}{ Single member districts } & & \multicolumn{2}{c}{ Multi member districts } \\
\cline { 2 - 3 } \cline { 5 - 6 } & $\begin{array}{c}N \\
\text { Women }\end{array}$ & $\begin{array}{c}\% \\
\text { Women }\end{array}$ & & $\begin{array}{c}N \\
\text { Women }\end{array}$ & $\begin{array}{c}\% \\
\text { Women }\end{array}$ \\
\hline Lithuania 2004 & $13 / 71$ & 18.3 & & $16 / 70$ & 22.8 \\
New Zealand 2002 & $19 / 62$ & 30.6 & & $16 / 51$ & 31.3 \\
Italy 2005 & $43 / 475$ & 8.8 & & $30 / 161$ & 18.6 \\
Monaco 2003 & $3 / 16$ & 18.8 & & $2 / 8$ & 25.0 \\
Germany 1998 & $76 / 328$ & 23.2 & & $130 / 341$ & 38.1 \\
\hline
\end{tabular}

Sources: Lithuania, http://www.vrk.lt/2004/seimas/rezultatai/rez_isrinkti_e_20_1.htm;Italy, http:// english.camera.it/;New Zealand, http://www.ps.parliament.govt.nz/mps.htm;Monaco, http:// assembly.coe.int;Germany, http://www.bundeswahlleiter.de/wahlen/download/abc2002e.pdf. 
Table 2 that almost the same proportions of women have been elected to the New Zealand parliament from the SMDs and the party lists in the multimember districts (Table 3).

Despite the general cross-national patterns, considerable variations in the representation of women were also clear within each major electoral family, as shown by the distribution shown in Figure 2. More women were elected in

Table 3 Statutory gender quotas in use worldwide

\begin{tabular}{|c|c|c|c|c|c|c|c|c|}
\hline Country & $\begin{array}{l}\text { Date } \\
\text { of law }\end{array}$ & $\begin{array}{c}\text { Gender } \\
\text { quota } \\
\%\end{array}$ & $\begin{array}{l}\text { Legislative } \\
\text { body }\end{array}$ & $\begin{array}{l}\text { Electoral } \\
\text { system }\end{array}$ & $\begin{array}{l}\text { List } \\
\text { open or } \\
\text { closed }\end{array}$ & $\begin{array}{c}\% \text { women } \\
\text { MPs before } \\
\text { law (i) }\end{array}$ & $\begin{array}{c}\% \text { women } \\
\text { MPs after } \\
\text { law (ii) }\end{array}$ & $\begin{array}{l}\text { Change } \\
\text { (i)-(ii) }\end{array}$ \\
\hline France & 1999 & 50 & Lower & Majoritarian & - & 11 & 12 & +1 \\
\hline Costa Rica & 1997 & 40 & Unicameral & Proportional & Closed & 14 & 19 & +5 \\
\hline Belgium & 1994 & 33 & Lower & Proportional & Open & 18 & 23 & +5 \\
\hline $\begin{array}{l}\text { Bosnia \& } \\
\text { Herzegovina }\end{array}$ & 2001 & 33 & Lower & Proportional & Open & & 14.3 & \\
\hline Argentina & 1991 & 30 & Lower & Proportional & Closed & 6 & 27 & +21 \\
\hline Peru & 1997 & 30 & Unicameral & Proportional & Open & 11 & 18 & +7 \\
\hline Venezuela & 1998 & 30 & Lower & Combined & Closed & 6 & 13 & +7 \\
\hline Panama & 1997 & 30 & Unicameral & Combined & Closed & 8 & 10 & +2 \\
\hline Venezuela & 1998 & 30 & Senate & Combined & Closed & 8 & 9 & +2 \\
\hline Bolivia & 1997 & 30 & Lower & Combined & Closed & 11 & 12 & +1 \\
\hline Mexico & 1996 & 30 & Senate & Combined & Closed & 15 & 16 & +1 \\
\hline Bolivia & 1997 & 30 & Senate & Combined & Closed & 4 & 4 & 0 \\
\hline Brazil & 1997 & 30 & Lower & Proportional & Open & 7 & 6 & -1 \\
\hline Mexico & 1996 & 30 & Lower & Combined & Closed & 17 & 16 & -1 \\
\hline Indonesia & 2003 & 30 & Lower & Proportional & Closed & 9 & $\mathrm{~N} / \mathrm{a}$ & $\mathrm{N} / \mathrm{a}$ \\
\hline Macedonia & 2001 & 30 & Lower & Combined & Closed & & 17.5 & \\
\hline Serbia & 2002 & 30 & Lower & Proportional & Open & 7.5 & $\mathrm{~N} / \mathrm{a}$ & $\mathrm{N} / \mathrm{a}$ \\
\hline $\begin{array}{l}\text { Dominican } \\
\text { Rep }\end{array}$ & 1997 & 25 & Lower & Proportional & Closed & 12 & 16 & +4 \\
\hline Ecuador & 1997 & 20 & Unicameral & Combined & Open & 4 & 15 & +11 \\
\hline Paraguay & 1996 & 20 & Senate & Proportional & Closed & 11 & 18 & +7 \\
\hline Paraguay & 1996 & 20 & Lower & Proportional & Closed & 3 & 3 & 0 \\
\hline Korea, North & - & 20 & Lower & Majoritarian & - & & 20.1 & \\
\hline Philippines & 1995 & 20 & Lower & Combined & Closed & & 17.8 & \\
\hline Armenia & 1999 & 5 & Lower & Combined & Closed & & 3.1 & \\
\hline Nepal & 1990 & 5 & Lower & Majoritarian & - & & 5.9 & \\
\hline $\operatorname{Iraq}^{\mathrm{a}}$ & 2005 & 25 & Lower & Proportional & Closed & & 31.5 & \\
\hline Average & & 30 & & & & 10 & 14 & +4 \\
\hline
\end{tabular}

Note: Statutory gender quotas for the lower house of national parliaments are defined as legal regulations specifying that each party must include a minimum proportion of women in their candidate lists. Change is estimated based on the percentage of women MPs in the parliamentary election held immediately before and after implementation of the gender quota law.

${ }^{\text {a}}$ The Iraqi Transitional National Assembly.

Sources: Htun (2001); Htun and Jones (2002); International IDEA. 


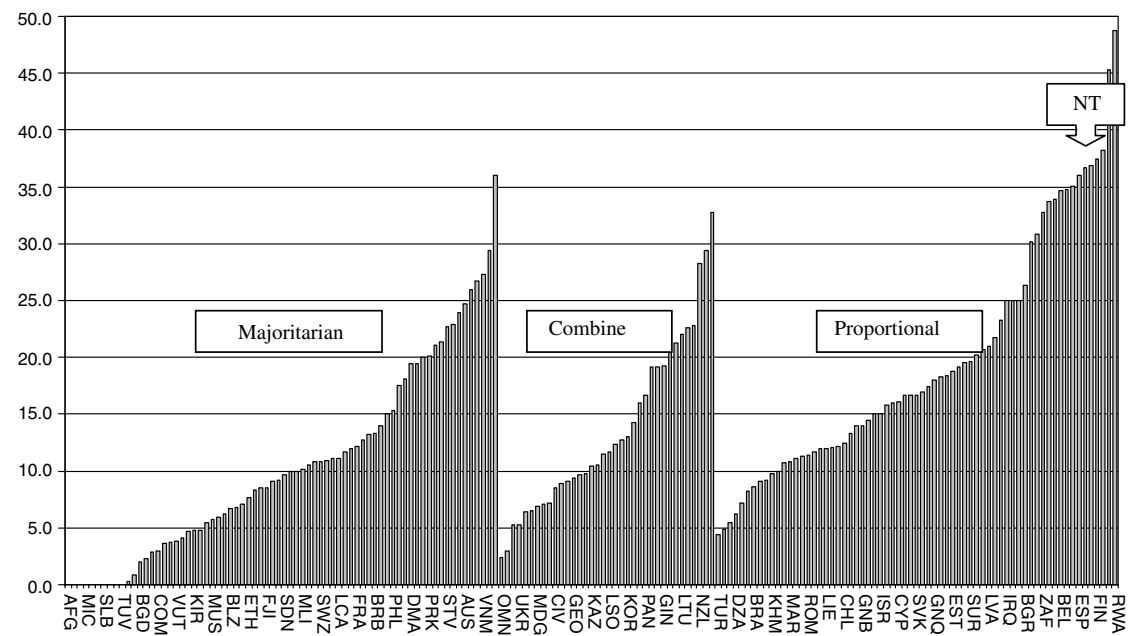

Figure 2 Countries classified by electoral systems and ranked by the percentage of women in the lower house of parliament, 2005. Source: Inter-parliamentary Union (2005).

certain majoritarian electoral systems, such as in Australia and Canada, than in some other highly proportional party list systems, as exemplified by Israel. Although there is a strong and consistent association, by itself the basic type of electoral system is neither a necessary nor a sufficient condition to guarantee women's representation.

These variations within families of electoral systems could be attributed to many intervening conditions, including:

- Average district magnitude (the mean number of candidates per district);

- Levels of proportionality;

- The use of statutory and voluntary gender quotas;

- Party ideologies (with parties on the left found to be generally more sympathetic towards gender equality); and

- The type of party organization.

To understand the reasons for the outcome, it helps to distinguish the different stages in the candidate selection process, using the model illustrated schematically in Figure 3. The type of electoral system, and the use of statutory quotas or reserved seats, regulates the context of the candidate selection process used within each party. The 'demand' of party selectors and the 'supply' of candidates interact to generate the pool of parliamentary candidates. In the final stage, demand by the electorate (for parties or candidates) determines the composition of parliament. 


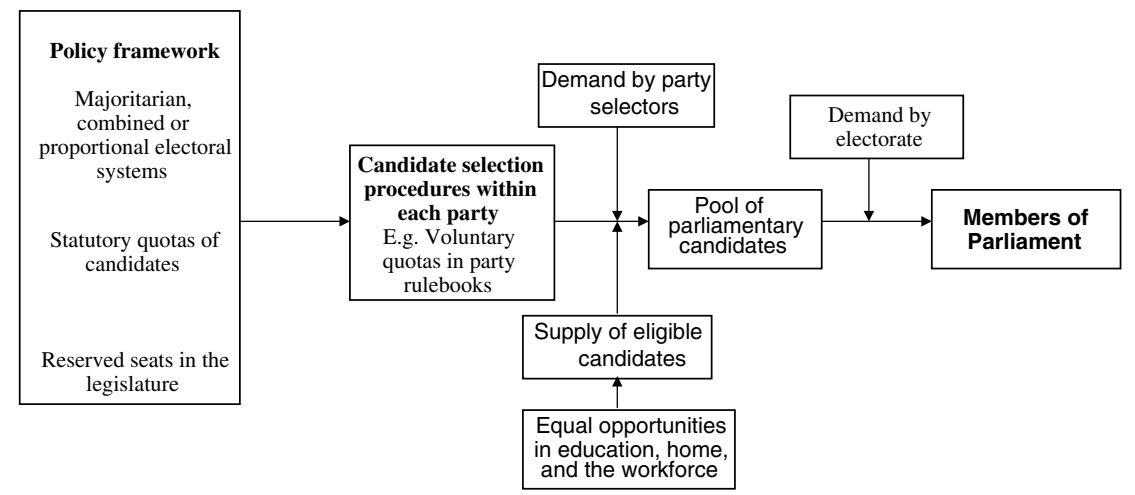

Figure 3 Stages in the candidate selection process.

Given this process, we can theorize that women usually benefit from PR for three possible reasons: party vote maximizing strategies; patterns of incumbency turnover; and the implementation of positive action strategies.

\section{Vote-maximizing strategies}

Under proportional systems, each party presents the public with their collective list of candidates for each multimember district. As such, parties have an electoral incentive to maximize their collective appeal in such lists by including candidates representing all the major social cleavages in the electorate, for example, by including both middle class professionals and blue-collar workers, rural farmers and urban shopkeepers, Catholics, Protestants and Muslims, as well as women and men. Multimember districts encourage collective party accountability for the complete list of candidates. The larger the district, the longer the candidate list, and the easier it is for the party to juggle all forms of social considerations to create a 'balanced' ticket. The smaller the list of candidates, the more difficult it is to include all groups. Where parties have to nominate a slate of candidates for a multimember district, the exclusion of any major social sector, including women or minorities, could signal discrimination, and could therefore risk an electoral penalty at the ballot box. By contrast in first-past-the-post systems, parliamentary candidates are selected to run within each single member district. Where the selection process is in the hands of the local constituency party, this creates minimal incentive for each particular constituency to pick a ticket that is 'balanced' at the district or national level. Local party members often want a representative who will maximize their chances of winning in that constituency, irrespective of the broader consequences for the party or parliament (Norris and Lovenduski, 
1995). The selection of the default option (i.e., a candidate reflecting the traditional characteristics and qualifications of previous parliamentarians) may be expected to predominate in many cases, as the rational vote-maximizing strategy designed to minimize electoral risks. Where parliaments remain disproportionately male, a risk-averse strategy increases the probability that in SMDs, selectorates will probably select another man.

\section{Incumbency turnover}

Moreover rates of incumbency turnover play a role. One major barrier to women and minority candidates lies through the strength of incumbency, with elected officials returned over successive contests, due to the personal vote advantages of familiarity, name recognition, and media attention, as well as greater financial and organizational resources that accompany legislative office (Somit et al., 1994). In many contests the key challenge facing women and minorities is not just becoming a candidate, but contesting a winnable seat in single-member districts, or being ranked near the top of the party list of candidates in PR systems. Matland and Studlar's (2004) comparison of election to the lower house of the national parliament in 25 established democracies from 1979 to 1994 found that on average about two-thirds of all incumbents were returned from one general election to the next, including $66 \%$ in PR electoral systems and $70 \%$ in majoritarian elections. This difference is modest but it could generate slightly more opportunities for challengers, including 'outgroups' in the pipeline for elected office. In Britain, for example, it was Labour's landslide in 1997, coupled with the use of positive action placing women in target seats, which doubled the number of women in the UK House of Commons. As incumbents, Labour women MPs were re-elected in the 2001 British general election, despite the fact that the original positive action strategy was discontinued. In the United States, Carroll and Jenkins (2001) established that from 1998 to 2000 women increased their numbers in states with term limitations more than elsewhere, although this effect was reversed in states like California where women representatives have already made much progress. In general, $85 \%$ of incumbent congressional representatives have been returned in successive US election from the late 1970s to the mid-1990s, reducing the opportunities for new candidates (Caress 1999).

\section{Implementation of positive action strategies}

Party list PR also facilitates the implementation of positive action strategies used for women and minorities. Candidate quotas can also be used under majoritarian electoral systems as well, as shown by the British Labour party, but it can be harder to implement quotas within single member districts than 
within party lists. Reserved seats can also be used within majoritarian electoral systems, for example in New Zealand for Maoris prior to reform, but reserved seats have been less commonly employed in most established democracies. For all these reasons, PR systems are more likely to produce more women in parliament than majoritarian electoral systems. In terms of the options being debated for the Dutch electoral system, the introduction of an open list system would probably have minimal impact upon gender equality. The adoption of a combined-dependent system with SMDs, such as that used in Germany, would probably reduce the proportion of women in the Tweede Kamer, as would the de Graaf proposal of a combined-dependent system with SNTV, for all the reasons already discussed.

\section{Statutory Quotas}

If the Netherlands opts for an electoral system with some single member districts, then what else could be done to promote women's opportunities in parliament? One option would be for parliament to introduce statutory quotas specifying that women or minorities must constitute a specified minimal proportional of parliamentary candidates within each party. Statutory quotas are implemented by law and they would apply to all parties contesting an election. This strategy should be distinguished from voluntary quotas, which are decided by each party and implemented by the internal party regulations and rule books. Quotas can be specified for women and men, and for other relevant forms of ethnic identity, such as nationality, language, religion, and for indigenous groups. Statutory gender quota laws have been applied to European and Latin American elections (see Table 4), as well as for appointments to public bodies and consultative committees, for example in Finland and Norway (Peters et al., 1999; Caul, 2001; Dahlerup, 2005).

As shown by the last column in Table 4, monitoring short-term change in the election immediately before and after passage of the law, in some countries, and in some elections, the introduction of statutory gender quotas appears to have worked far more effectively than in other cases. Hence the substantial rise in women in parliament found in Argentina, and the modest growth in Peru and Belgium, but minimal progress evident in France, Mexico, or Brazil. Why is this? The effective implementation of statutory gender quotas depends upon multiple factors, including most importantly:

- How the statutory mechanisms are put into practice;

- The level of the gender quota specified by law;

- Whether the rules for party lists regulate the rank order of women and men candidates;

- Whether party lists are open or closed; 
Table 4 Reserved seats for women used in the lower house of parliaments worldwide

\begin{tabular}{lccccl}
\hline Election & $\begin{array}{c}\text { Total number } \\
\text { of MPs in the } \\
\text { lower house }\end{array}$ & $\begin{array}{c}\text { Number of } \\
\text { seats reserved } \\
\text { for women }\end{array}$ & $\begin{array}{c}\text { \% Of seats } \\
\text { reserved for } \\
\text { women }\end{array}$ & $\begin{array}{l}\text { Appointed or } \\
\text { elected }\end{array}$ \\
\hline Uganda & 2001 & 292 & 56 & 19.1 & Indirectly elected \\
Pakistan & 2002 & 357 & 60 & 16.8 & Elected \\
Tanzania & 2000 & 295 & 48 & 16.2 & Appointed \\
Zimbabwe & 2000 & 274 & 37 & 13.5 & Appointed \\
Djibouti & 2003 & 65 & 7 & 10.7 & Elected \\
Bangladesh & 2001 & 300 & 30 & 10.0 & Appointed \\
Sudan & 2000 & 360 & 35 & 9.7 & Elected \\
Morocco & 2002 & 325 & 30 & 9.2 & Elected \\
Botswana & 1999 & 44 & 2 & 4.5 & Appointed \\
Lesotho & 1998 & 80 & 3 & 3.8 & Appointed \\
Taiwan & 1996 & 334 & Varies & Varies & Elected \\
Afghanistan & 2005 & 249 & 68 & 27 & Elected \\
\hline
\end{tabular}

Note: Reserved seats for women in the lower house of the national parliament are defined as those that by law can only be filled by women, either by appointment or election. It should also be noted that in Nepal three seats are reserved for women in the upper house, according to the 1990 constitution.

Sources: The Electoral Institute of Southern Africa (EISA), www.eisa.org.za; Elections Around the World, www.electionworld.org; International IDEA, www.IDEA.int.

- The mean district magnitude;

- Good faith compliance by parties; and also

- The penalties associated with any failure to comply with the law.

Positive action policies alter the balance of incentives for the party selectorate. Where these laws are implemented, then selectors need to weigh the potential penalties and benefits if they do or do not comply. Selectors may still prefer the default option of nominating a male candidate under certain circumstances, for example if the laws are designed as symbolic window-dressing more than as de facto regulations; if the regulation specify that a certain proportion of women have to be selected for party lists but they fail to specify their rank order so that female candidates cluster in unwinnable positions at the bottom of the list; or if any sanctions for non-compliance are weak or nonexistent. There may also be lagged effects, as parties adapt gradually to the new regulatory environment and as incumbents retire. As in many attempts to alter incentive structures, the devil lies in the practical details and superficially similar legislative policies may turn out to have different consequences in different nations. 


\section{Reserved Seats}

An alternative policy option for the Dutch parliament would be the introduction of some reserved seats that would be only open to contestation by women candidates. This policy has been adopted to boost women's representation in local government in India, as well as to represent Maoris in New Zealand. Reserved seats have also been used in some developing nations in Africa and South Asia, particularly those with a Muslim culture, including for the lower house in Morocco, Afghanistan, Bangladesh, Pakistan, Botswana, Taiwan, Lesotho, and Tanzania (see Table 4) (Reynolds, 2005).

One advantage of this mechanism is that it guarantees a minimum number of women in elected office, without the uncertainty that arises from the implementation of statutory quotas. Critics argue, however, that the use of reserved seats may be a way to appease, and ultimately sideline, women. Being elected through this route does not necessarily mean that women would be given independent decision-making power or equal status as elected members. Where women members are appointed to reserved seats by the president or chief executive, they lack an independent electoral or organizational base, and this may reinforce control of parliament by the majority party (Tinker, 2004). Nevertheless against these arguments, where women standing for reserved seats face free and fair contested elections then they have an independent electoral base.

\section{Voluntary Gender Quotas}

An alternative policy concerns the use of voluntary gender quotas within specific parties. In this regard, while party leaders can take the initiative, this is not a matter which parliament could implement through electoral law. Rules, constitutions, and internal regulations determined within each party are distinct from electoral statutes enforceable by the courts. Parties in the Netherlands have used affirmative action strategies for women although, with the exception of Labour and Green Left, most have been reluctant to adopt quotas (Leijenaar, 2004). Voluntary gender quotas are widely used by many parties in Scandinavia, Western Europe, and Latin America, and Communist parties in Central and Eastern Europe employed them in the past (Caul, 2001; Dahlerup, 2005).

International IDEA's Global Database of Quotas for Women (2005) estimates that 181 parties in 58 countries use gender quotas for electoral candidates for national parliaments. The effects of these measures can be analyzed by focusing on their use within the European Union. By 2000, among 76 relevant European parties (with at least 10 members in the lower house), almost half (35 parties) used gender quotas, and 24 of these have achieved levels of female representation in the lower house of parliament of over $24 \%$. Among 
the European parties using gender quotas, on average one-third (33\%) of their elected representatives were women. By contrast, in the European parties without gender quotas, only $18 \%$ of their members of parliament were women.

Nevertheless it might be misleading to assume any simple 'cause' and 'effect' at work here, since parties more sympathetic towards women in public office may also be more likely to implement gender quotas. European parties of the left commonly introduced voluntary gender quotas during the 1980s, including Social Democratic, Labour, Communist, Socialist and Greens parties, before the practice eventually often spread to other parties.

Moreover, the 'before' and 'after' test suggests that the effects of voluntary gender quotas within parties vary substantially, exemplified by the outcome in Scandinavia, Germany, and Britain. In general there are fewer guarantees that voluntary positive action strategies will work, compared with the legal policies of statutory quotas or reserved seats. At the same time, letting parties decide whether to implement gender quotas gives them greater control over these matters and preserves their autonomy as voluntary associations in civil society.

\section{Conclusions and Summary}

International agencies, governments, parties and groups concerned with increasing the representation of women and minorities have advocated a range of initiatives designed to break through the barriers in elected office. The evidence presented in this study provides further confirmation that the basic type of electoral system influences the inclusiveness of elected bodies. Women are generally more successful in being nominated and elected under proportional electoral systems than under combined or majoritarian systems. Under PR, especially systems with a large district magnitude, parties have considerable incentive to create a balanced list of candidates, to avoid any electoral penalties from the appearance of discrimination against any particular group. This electoral incentive is absent among local selectors with single member districts in majoritarian elections, where each local party can choose an individual candidate without any collective responsibility for balancing the social profile of the parliamentary party at national level.

The general conclusion is that reforms, in the Netherlands, that amend the nationwide system of proportional representation need to consider their impact upon gender equality. In particular, the introduction of a combined dependent system with some SMDs will probably serve to reduce the proportion of women in the Tweede Kamer. The adoption of a combined dependent system with SNTV (the De Graaf proposal) would probably also reduce the proportion of women in the Tweede Kamer, although probably to a lesser extent than the adoption of a combined dependent system with SMDs. What 
matters for women's representation with the De Graaf proposal would be the mean size of the district magnitude used for the SNTV seats. Other reforms that are under debate in the Netherlands include the use of open lists, which would probably have little, if any, systematic effect upon women's election.

To compensate for any anticipated reduction in the proportion of women in parliament, reformers should also consider implementing other compensatory policies that have proved effective for maintaining social diversity in elected office. Parliament should consider the use of statutory quotas regulating the candidate selection processes in all parties or the use of reserved seats in the legislature, while parties should consider the implementation of voluntary quotas with higher levels in party rulebooks.

\section{References}

Bergqvist, C., Borchorst, A., Christensen, A., Ramstedt-Silén, V., Raaum, N.C. and Styrkársdóttir, A. (eds.) (1999) Equal Democracies? Gender and Politics in the Nordic Countries, Olso: Scandinavian University Press.

Caress, A.N. (1999) 'The influence of term limits on the electoral success of women', Women \& Politics 20(3): 45-63.

Carroll, S.J. and Jenkins, K. (2001) 'Unrealized opportunity? Term limits and the representation of women in state legislatures', Women \& Politics 23(4): 1-30.

Carroll, S.J. (ed.) (2001) The Impact of Women in Public Office, Indiana: University of Indiana Press.

Caul, M. (2001) 'Political parties and the adoption of candidate gender quotas: a cross- national analysis', The Journal of Politics 63(4): 1214-1229.

Council of Europe (2000) 'Positive Action in the Field of Equality Between Women and Men', Final report of the Group of Specialists on Positive Action in the field of equality between women and men (EG-S-PA).

Dahlerup, D. (ed.) (2005) Women, Quotas and Politics, New York: Routledge.

Dolan, J. (1997) 'Support for women's interests in the $103^{\text {rd }}$ Congress: the distinct impact of congressional women', Women \& Politics 18(4): 81-94.

Duerst-Lahti, G. and Kelly, R.M. (eds.) (1995) Gender, Power, Leadership and Governance, University of Michigan Press.

Human Rights Commission (2004) New Zealand Census of Women's Participation, Wellington, New Zealand.

Htun, M. (2001) 'Electoral rules, parties, and the election of women in Latin America' Paper for the Annual Meeting of the American Political Science Association, San Francisco, 30 August 2001.

Htun, M. and Jones, M. (2002) 'Engendering the Right to Participate in Decision-making: Electoral Quotas and Women's Leadership in Latin America' in N. Craske and M. Molyneux (eds.) Gender and the Politics of Rights and Democracy in Latin America, London: Palgrave.

Inglehart, R. and Norris, P. (2003) Rising Tide: Gender Equality and Cultural Change, New York: Cambridge University Press.

International IDEA Global Database of Quotas for Women, Available at www.idea.int.

International, IDEA (2005) Global Database of Quotas for Women, http://www.idea.int/quota/ index.cfm. 
Inter-Parliamentary Union (2005) Women in National Parliaments, Available at www.ipu.org 30 June 2005.

Inter-Parliamentary Union (2005) Women in Parliament Database, Available at www.ipu.org.

Karvonnen, L. and Selle, P. (1995) Women in Nordic Politics, Aldershot: Dartmouth.

Kenworthy, L. and Malami, M. (1999) 'Gender inequality in political representation: a worldwide comparative analysis', Social Forces 78(1): 235-269.

Latner, M. and McGann, A.J. (2004) 'Geographical representation under proportional representation: the cases of Israel and the Netherlands', Paper at Scholarship Repository, University of California; http://repositories.cdlib.org/csd/04-09.

Leijenaar, M. (2004) Political Empowerment of Women: The Netherlands and Other Countries, Leiden: Martinus Nijhoff Publishers.

Lovenduski, J. and Norris, P. (1993) Gender and Party Politics, London: Sage.

Mansbridge, J. (1999) 'Should blacks represent blacks and women represent women? A contingent 'yes”, Journal of Politics 61(3): 628-657.

Matland, R. (1998) 'Women's representation in national legislatures: developed and developing countries', Legislative Studies Quarterly 23(1): 109-125.

Matland, R. and Studlar, D. (2004) 'Determinants of legislative turnover: a cross-national analysis', British Journal of Political Science 34: 87-108.

Moser, R.G. (2001) 'The effects of electoral systems on women's representation in post-communist states', Electoral Studies 20(3): 353-369.

Norris, P. (1985) 'Women in European legislative elites', West European Politics 8(4): 90-101.

Norris, P. (1998) Passages to Power, Cambridge: Cambridge University Press.

Norris, P. (2004) Electoral Engineering, Cambridge: Cambridge University Press.

Norris, P. and Lovenduski, J. (1995) Political Recruitment: Gender, Race and Class in the British Parliament, Cambridge: Cambridge University Press.

OECD (2005) Trends in International Migration, Paris: SOPEMI, OECD: http://stats.oecd.org.

Peters, A., Seidman, R. and Seidman, A. (1999) Women, Quotas, and Constitutions: A Comparative Study of Affirmative Action for Women under American, German and European Community and International Law, The Hague: Kluwer Law International.

Phillips, A. (ed) (1998) Feminism and Politics, Oxford: Oxford University Press.

Phillips, A. (1995) The Politics of Presence, Oxford: Clarendon Press.

Pitkin, H. (1967) The Concept of Representation, Berkeley: University of California Press.

Reingold, B. (2000) Representing Women: Sex, Gender, and Legislative Behavior in Arizona and California, Chapel Hill: University of North Carolina Press.

Reynolds, A. (1999) 'Women in the legislatures and executives of the world: knocking at the highest glass ceiling', World Politics 51(4): 547-572.

Reynolds, A. (2005) 'Reserved seats in national legislatures.', Legislative Studies Quarterly 30(2): 301-310.

Russell, M. (2001) 'The Women's Representation Bill: making it happen', The Constitution Unit Report, University College, London.

Siaroff, A. (2000) 'Women's representation in legislatures and cabinets in industrial democracies', International Political Science Review 21(2): 197-215.

Somit, A., Wildenmann, R., Boll, B. and Rommele, A. (eds). (1994) The Victorious Incumbent: A Threat to Democracy?, Aldershot: Dartmouth.

Swers, M. (1998) 'Are women more likely to vote for women's issue bills than their male colleagues?' Legislative Studies Quarterly 23(3): 435-448.

Swers, M. (2001) 'Understanding the policy impact of electing women: Evidence from research on congress and state legislatures', PS: Political Science and Society 34(2): 217-220.

Tinker, I. (2004) 'Quotas for women in elected legislatures: do they really empower women?' Womens Studies International Forum 27(5-6): 531-546. 
Tremblay, M. and Pelletier, R. (2000) 'More feminists or more women? Descriptive and substantive representations of women in the 1997 Canadian federal elections', International Political Science Review 21(4): 381-405.

Tremblay, M. (1998) 'Do female MPs substantively represent women?' Canadian Journal of Political Science 31(3): 435-465.

United Nations (1995) The Beijing Declaration 1995, Section 13. Available at www.unifem.undp. org $/$ beijing +5 .

United Nations Development Programme (2002) Human Development Report 2002, New York: Oxford University Press.

\section{Note}

1 It should be noted that this may underestimate numbers as it does not classify any secondgeneration ethnic minority representatives, for example if one or both of their parents was born in Turkey, Suriname or Morocco. See http://www.houseofrepresentatives.nl/members_of_parliament/ mps/index.jsp 